\title{
Network Governance and the Making of Brazil's Foreign Policy Towards China in the $21^{\text {st }}$ Century*
}

Daniel Cardoso**

\section{Abstract}

Driven by China's increasing global influence, China-Brazil relations have deepened significantly in the 21 st century; for Brazil, this bilateral relationship has become one of the most important aspects of its foreign relations. This article aims at analysing how Brazil's foreign policy towards China was made and implemented during the eight years of Luiz Inácio Lula da Silva's presidency, and the first four years of Dilma Rousseff's presidency. While scholars agree that the Ministry of Foreign Affairs did not exclusively dominate this policy, little is known about which state and non-state actors were involved, how and why they interacted, and how their interactions influenced policy choices. The article starts by identifying the actors that played a significant role in formulating Brazil's China policy. Next, drawing on the concept of network governance, it explores the processes and mechanisms that governed the interactions among them. It concludes with an assessment of the democratic quality of this policy area.

Keywords: Brazil, China, Foreign Policy, Network Governance, Domestic Politics.

\footnotetext{
* Received on 30 October 2015 and approved for publication on 11 January 2016.

** Berlin Forum on Global Politics, Berlim, Germany; daniel.oliveira.cardoso@gmail.com
} 


\section{Introduction}

The first decade of the $21^{\text {st }}$ century marked a new phase in China's economic and political rise. After more than three decades of sustained economic growth, China started to expand its economic and political influence across the globe. Even though this 'going global' strategy had been in the making for several years, it only materialised in the 2000s (Shambaugh 2013: 6). One of the central elements of China's global strategy was the strengthening of relations with other developing countries in Africa, the Middle East, and Latin America. Brazil, the largest economy in Latin America, politically influential, and the sponsor of several regional institutions, was particularly exposed to China's increasing regional and global influence.

This article will analyse how the response to China's new global role was formulated and implemented during the eight years of Luíz Inácio Lula da Silva's presidency (2003-2010), and the first four years of Dilma Rousseff's presidency (2011-2014). ${ }^{1}$ Despite a few initiatives during Fernando Henrique Cardoso's second term, notably a trade mission to China in 2002, the change in presidency in 2003 meant that it was up to Lula da Silva's and subsequent administrations to cope with China's increasing influence in the $21^{\text {st }}$ century.

This analysis is based on two interrelated premises. The first is the agency of the state in the international system. While structural dynamics such as market forces, increasing bilateral interdependence, and the international distribution of power are relevant, the analysis departs from the idea that they provide the context in which purposeful states act. Indeed, the agency of the state is at the centre of Hill's definition of foreign policy, which he describes as 'the sum of official external relations conducted by an independent actor (usually a state) in international relations. Policy is 
the "sum" of these official relations $[\ldots]$ and it implies conscious intentions and coordination' (Hill 2002: 3-5).

If we assume that states are indeed able to choose and, to some extent, creatively construct their relations with other states, it is legitimate to ask how they arrive at the choices they make about these relations. This implies, as Alden and Aran suggest, looking not only at the 'actors involved in the state's formal decision-making apparatus, but also the variety of sub-national sources of influence upon state foreign policy' (Alden and Aran 2012: 1). This, then, is the second premise: states are not unitary, and it is therefore necessary to open the 'black box' and assess how their actions are influenced by their internal dynamics. These two premises serve as the points of departure for analysing the domestic conditions and factors influencing Brazil's China policy in the $21^{\text {st }}$ century.

Other scholars have addressed this theme, but the role of domestic actors in the formulation of Brazil's China policy is still insufficiently understood. While Ramanzini Júnior and Ribeiro (2013: 175) regard the involvement of domestic actors in the policy process as 'limited', Barbosa and Mendes (2008), Biato Junior (2010), Pereira and Neves (2011), and Spektor (2011) confirm the relevance of domestic politics, but leave some questions unanswered: which actors were involved in the policy process, and which were excluded? What types of resources were relevant to policy formulation, and how were they distributed among domestic actors?

This article seeks to provide answers to these questions, and fill this gap in the literature, by drawing on a specific theoretical framework. More specifically, it uses the concept of network governance to shed light on the mechanisms through which domestic politics influenced Brazil's policy towards China. In general terms, governance means the way in which public policy-making is organised - that is, how actors, whether state or non-state, contribute to the political 
regulation of social affairs and the provision of common goods (Mayntz 1998). Given its centrality, the examination of any public policy should start with this concept. However, in foreign policy analysis, modes of governance are rarely discussed and theorised. As a result, most studies of foreign policy-making take for granted the mode of governance that emerged with the establishment of modern public administration in the beginning of the $20^{\text {th }}$ century, in terms of which policy (government and bureaucracy) was meant to be separated from politics (society). However, this mode of governance has gone through several changes since the 1970s, intended to create more space for non-state actors in public policy-making. In this context, the concept of network governance makes it possible to study foreign policy-making by taking into consideration this shift from 'government to governance' - the 'governance turn', to use the term coined by Risse (2013). Drawing on this analytical framework, the article argues that state and non-state actors in Brazil recurrently interacted in an attempt to jointly govern relations with China.

The analysis is based on qualitative field work as well as desktop work. Secondary sources include articles from books, journals and newspapers. The field work was conducted in China (from August 2011 to January 2012) and, mostly, in Brazil (from November 2012 to December 2012), and consisted of face-to-face interviews. The interviewees were officials in the ministries of foreign affairs and trade, representatives of the export sector and of trade unions, and experts on Brazil's foreign policy. All the interviews informed the research as well as the analysis. Seventeen interviews were conducted, five of which are quoted.

The study starts with a discussion of the analytical framework, aimed at defining the concept of network governance and inserting it into the analysis of the domestic sources of foreign policy. Next, the transition of modes of governance in Brazil is analysed. Following this, the theoretical considerations are used as a framework for 
studying the conditions under which domestic actors interacted to make Brazil's policy towards China. The analysis largely focuses on Lula da Silva's administration, followed by an assessment of the continuities and changes during Rousseff's first term. The study concludes with a summary of the main findings.

\section{Domestic sources of foreign policy: a view from network governance}

The idea that the international system consists of unitary states whose behaviour is exclusively shaped by structural forces dominated international relations thinking for most of the $20^{\text {th }}$ century. Only after the publication of seminal works by Snyder et al. (1962) and Rosenau (1967), domestic dynamics started to gain relevance as an explaining variable of states' international actions. However, this relevance waned in the 1970s and 1980s as systemic explanations of international relations, led by the structural realism of Kenneth Waltz (1979), gained prominence.

The end of the Cold War contributed to a revival of domestic variables in international relations research. The collapse of the bipolar system accelerated economic liberalisation, democratisation, and the spread of information and telecommunications technologies (ICT), bolstering the interconnections among states. In this context, almost every policy area that states had to deal with gained an 'international dimension', leading to a pluralisation of actors with a 'stake' in international affairs (Macleod 2002). Therefore, national societies became not only more integrated, but also more fragmented.

Against this background, several authors argued that the specific choices of states about their foreign relations could only be properly understood by considering the role of domestic actors (Evans, 
Jacobson and Putnam 1993; Milner 1997; Moravcsik 1997). These actors were regarded as relevant for two reasons. First, since the way in which states respond to globalisation has effects (either relative or absolute) on societies, domestic actors are interested in shaping the direction of states' decisions. Second, domestic actors have several types of resources that are relevant to the formulation and implementation of foreign policy. According to Moravcsik (1994: 1), there are four types of resources: institutions (the procedures by which domestic decisions are made); information or expertise (political and technical knowledge); initiative (the authority to introduce - or to block the introduction of - issues onto the domestic agenda); and ideas (labelling the problem, or the supply of legitimate ideological justification for specific policies). Financial resources are also important.

Even though the authors mentioned above were instrumental for a better understanding of the domestic sources of foreign policy, they rarely referred to changes in state governance as one of the conditions for the increasing participation of domestic actors in foreign policy-making after the Cold War. This is because studies of foreign policy tend to take as given the bureaucratic-hierarchical mode of governance in which state actors (executive, legislative and bureaucratic) are the only relevant policy-makers. The nature of the state and the modes of governance underlying foreign policy-making are rarely discussed. However, such a discussion is essential because the mode of governance in place - either based on hierarchy, markets, or networks - determines how the public policy-making process and state-society relations are organised. This means that it has a selective effect in that it helps to determine the constellation of actors that can be legitimately included in the policy-making process.

The hierarchical bureaucratic mode of governance, which organised state-society relations across the world during most of the $20^{\text {th }}$ century, determined that the executive and bureaucratic arms of the 
state had to be insulated from society in order to 'avoid the collective irrationalities of the electorate and prevent strong, organized interests from taking control of state policy. The goal was to increase the efficiency of public policies by insulating them from politics' (Bevir 2010: 25-26). In this conception, public policies were formulated within the state apparatus, and then imposed on society.

However, this approach has lost ground since the 1970s, opening the way to patterns of governance based on markets and networks. In the face of the challenges brought by globalisation and the fragmentation of political and social life, network governance arose as a way to bring together the resources of interdependent state and non-state actors in order to increase the possibility of reducing uncertainty, overcoming complexity, and increasing the efficiency of policies (Sørensen and Torfing 2009). ${ }^{2}$ While, during the bureaucratic-hierarchical period, the goal was to limit the role of non-state actors who could only influence policy from the 'outside', network governance aims at allowing those actors to work alongside state actors in shaping policy from 'inside'. In this sense, governance through networks means that there is a constellation of 'interdependent yet autonomous actors engaged in institutionalized processes of public governance based on negotiated interactions and joint decision making' (Sørensen and Torfing 2009: 237). These networks between state and non-state actors tend to be horizontal, in that they have no formal leader; voluntary, in that actors choose to participate, and can leave it at any point; and reciprocal, in that actors exchange resources, and expect to get something out of the network (Sikkink 2009: 230). ${ }^{3}$

However, as noted by Börzel (2010), modes of governance build on, rather than completely replace, one another. This means that networks usually operate informally under the supervision or management of the state, in the 'shadow of hierarchy'. In this sense, the state is a manager, concerned with 'metagovernance', or the governance of governance (Marsh 2008). 
Brazilian scholars have done a lot of work on the impact of globalisation, liberalisation and democratisation on the process of making and implementing foreign policy (Figueira 2009; Hirst, Lima and Pinheiro 2010; Pinheiro and Milani 2012; de Faria 2012; de Faria, Lopes and Casarões 2013). These authors agree that, due to those three factors, the separation between the domestic and international dimensions was increasingly blurred, paving the way for the pluralisation of actors in Brazil's foreign policy-making. This loosened the strong grip of the Ministry of Foreign Relations (MRE, or Itamaraty) on the policy process, which became more plural, politicised, competitive, and messy. Yet these changes in Brazil's foreign policy-making process have been rarely analysed from a governance perspective. The dialogue between foreign policy analysis and governance studies is particularly useful in the case of Brazil because the historic insulation of Itamaraty represents one of the clearest examples of the bureaucratic hierarchy paradigm in action. Hence it is relevant to assess how the changes (either material or ideational) to governance in Brazil since the 1990s affected the traditional foreign policy-making process.

In the next section, drawing on the analytical framework, the evolution of Brazil's modes of governance and their effects on the formulation of foreign policy will be analysed. This step is relevant in order to assess, once the article turns to the case study, the structural conditions underlying the formulation of Brazil's foreign policy towards China, namely the room for the legitimate participation of non-state actors in the policy process.

\section{From bureaucratic hierarchy to network governance}

The bureaucratic-hierarchical mode of governance in Brazil started in the 1930s. In 1938, the government created the Administrative 
Department of Public Service in order to centralise public policy-making, and insulate it from society (Silva and Amaral 2007: 10). This reform was crucial for Itamaraty since it created some of the foundations of its insulation, namely the establishment of a diplomatic academy, and the building of a specific ethos within the ministry (Figueira 2009: 137; de Faria 2008: 81). From the 1970s onwards, after several decades of consolidation and pre-eminence, the efficacy of this mode of governance was increasingly questioned. This process was not confined to Brazil; there was a worldwide trend towards scepticism about the weight of the state in the economy and society. As shown in the previous section, the general assessment was that, due to the increasing complexity of world affairs as a result of globalisation and the emergence of organised civil society in the 1970s, states could no longer govern efficiently on their own, necessitating a transition to more modern forms of governance (Sørensen and Torfing 2007). Neoliberalism and its application to public administration through what became known as 'New Public Management' emerged as the first response to these concerns about state governance (Bevir 2010: 67). The emergence of neoliberalism converged with what Samuel Huntington labelled the 'third wave of democratization' - that is, a process of democratisation in more than 30 countries between 1974 and 1990 (Huntington 1991: 12). These two trends, combined with globalisation and the end of the Cold War, provided the backdrop to the changes in Brazil's governance from the late 1970s onwards.

The first attempts to revise the centralised and bureaucratic nature of the Brazilian state were the 1979 National Plan of Debureaucratisation, and the 1988 Constitution (Silva and Amaral 2007: 10). Due to strong resistance from the state bureaucracy, both initiatives failed. In the 1990s, during the presidencies of Collor de Mello and Fernando Henrique Cardoso, efforts continued to reform the Brazilian state. In 1995, Cardoso established the Ministry of 
Federal Administration and State Reform (MARE), headed by Luiz Carlos Bresser-Pereira, who put together a master plan for reforming the state apparatus. It comprised a threefold strategy, namely to 'strengthen the state's capacity to regulate and coordinate, especially at a federal level; gradually decentralize social and infra-structure services to state and municipal levels [...]; and make public administration more permeable to the participation of private actors and/or civil society organisations' (Brazil 1995). As noted by Bresser-Pereira (2002: 11), reform in Brazil was based on reforms that 'had already been launched in several members of the Organisation for Economic Co-operation and Development (OECD), especially the United Kingdom' (Bresser-Pereira 2002: 11).

Regarding foreign policy-making, the reforms did not profoundly change the bureaucratic-hierarchical model on which the MRE was based (Figueira 2009: 154). However, several changes were introduced that were intended to loosen the institution's grip on the process, bringing it closer to the network governance model. According to Sebastião Rego Barros, Itamaraty's general secretary under Cardoso, the ministry created several mechanisms, including the National Secretary for the Free Trade Agreement of the Americas (SENALCA), the Office for Federative and Parliamentary Relations, and the Centre for the Promotion of Trade Efficiency (CPEC), that sought to 'bring the institution and society increasingly closer and [...] to coordinate the positions of ministries, other state and non-state bodies' (Barros 1998: 18). Cardoso's administration also established interministerial agencies focused on international trade, including the Brazilian Trade and Investment Promotion Agency (APEX), and the Foreign Trade Council (CAMEX) (Cason and Power 2009: 121). Furthermore, several ministries established dedicated offices to deal with international linkages. Even though this was not a novelty, as noted by Silva et al. (2010: 17), this trend grew stronger from the 1990s onwards because of the increasing 
interconnection between domestic and international agendas in various policy areas (Figueira 2009: 156-157; de França and Sanchez 2009; Pinheiro and Milani 2013: 17).

However, the biggest achievement, according to those involved in the process of reforming the Brazilian state in the mid-1990s, was in the realm of ideas. The reform changed what Fernando Henrique Cardoso characterised as a 'political culture based on a notion of state and society that no longer fit[ted] the demands of Brazilian society' (Cardoso 1995). According to Bresser-Pereira (2007: 35), in 1998 'there was almost a consensus among public opinion and elites on the need to reform the state in order make it modern'. What Cardoso and Bresser-Pereira were suggesting was that, after the 1995 state reform, the dominant idea about state governance in Brazil changed from bureaucratic hierarchy to network governance.

This new understanding of governance provided the foundation for the Lula da Silva administration's vision of state-society relations. The 2004-2007 Pluriannual Plan ${ }^{4}$ stated that 'in order to increase its capacity to efficiently achieve results, the state has to widen the room for dialogue, partnership and co-responsibility with society' (Brazil 2004: 7). According to Cervo, Lula da Silva continued and deepened the notion of the 'logistic state' which served as the foundation of Cardoso's reforms. In Cervo's words, the state is 'logistic' because it 'recovers the developmental strategic planning, and serves as support and legitimisation of the initiatives from other economic and social actors, to which it transfers responsibility and power' (Cervo 2012: 37).

Itamaraty soon began to address its goal of promoting the involvement of other state as well as non-state actors in foreign policy-making. In his inaugural address as minister of foreign affairs, Celso Amorim stated that 'to define the national interest in each specific situation, I will strengthen the coordination with other 
government bodies and with several sectors of society - workers, businessmen, intellectuals - and civil society entities' (Amorim 2003). This intention was put into to practice through two reforms (2004 and 2006) which established more channels of communication with other actors, and further fragmented the structure of the ministry by creating new thematic sections (Figueira 2009: 144).

As Figueira (2009) points out, the shift from the bureaucratic-hierarchical mode of governance to network governance in Brazil's foreign policy-making was incomplete, and the two modes coexisted during Lula da Silva's administration. Even though Itamaraty remained a hierarchical and cohesive body based on a strong professional ethos, it no longer fully centralised the policy-making process, having instead to operate within a network of state and non-state actors (Figueira 2009: 163). ${ }^{5}$ The institution remained influential, as attested by a cable from the US Ambassador to Brazil sent to the Department of State in Washington,DC (US Embassy 2009) as well as studies on this topic (de Faria 2012: 347; Figueira 2009: 192), but the need for its 'insulation' in order to have an efficient foreign policy vanished with the changes in the intersubjective understanding of how the policy process should be organised. The recipe for efficiency was no longer bureaucratic insulation, but co-ordination within a network of state and non-state actors. As noted by one of Souza's interviewees, 'the bureaucratic isolation of Itamaraty, which once allowed it to maintain its quality, became an obstacle' (de Souza 2001: 87).

To summarise, after Collor de Mello there was an intentional shift towards network governance, which, alongside globalisation, economic liberalisation and democratisation, formed the basis for the reconfiguration of public policy-making in Brazil. Under these circumstances, the choices of the Brazilian government about the 
conduct of its international affairs were more likely to be influenced by the interaction between domestic actors.

Drawing on these insights, the next section traces the participation of domestic actors in the making of Brazil's China policy during Lula da Silva's two terms in office, and the first four years of Rousseff's first term.

\section{Network governance and the making of Brazil's foreign policy on China}

Sino-Brazilian relations were limited until the 2000s. This changed as China acceded to the WTO in 2001, and started to extend its influence. In Latin America, Brazil stood out as one of the countries most heavily influenced by China's 'going global' strategy. ${ }^{6}$ Despite the considerable geographical and cultural distance, Brazil became relevant for China because of its economic and political features: resource-rich, large domestic market, technological sophistication in several sectors, and significant regional influence (Cardoso 2015). While a few initiatives were undertaken during Cardoso's term, it was mostly up to the next administration to find ways of coping with China's growing stature.

\section{Lula da Silva's presidency (2003-2010)}

An analysis of the formulation of Brazil's policy towards China during Lula da Silva's two terms in office (2003-2010) shows that, besides Itamaraty, other actors inside and outside the state apparatus were involved in the policy process. One of the most important ones was the president himself, ${ }^{7}$ who regarded China as a foreign policy priority. In his inaugural speech, he declared: 'We will deepen our relations with major developing nations like China, India, Russia, 
South Africa, among others' (da Silva 2003b). ${ }^{8}$ In fact, the president's interest in China started even before he assumed office. In 2001, while still a presidential candidate, he travelled to China to meet members of the CCP. ${ }^{9}$ From Beijing, he wrote: 'PT (Workers Party) made it clear that it considered to be in Brazil's and its nationals' best interest the widening of diplomatic, economic, cultural and technological relations with the Chinese nation' (da Silva 2001).

Besides the presidency, Itamaraty also had to give other ministries a role in making policy on China. The most important was the Ministry of Development, Industry and Commerce (MDIC). Since much of Brazil-China relations had to do with trade and investments, MDIC was increasingly relevant to the policy process. Moreover, MDIC did not play a role on its own - it also involved several other agencies, notably the Brazilian Development Bank (BNDES), CAMEX and APEX, under its aegis.

The analysis of Lula da Silva's terms reveals several examples of network governance in which state actors interacted with non-state actors in the process of making and implementing China policy. Indeed, since the very beginning of Lula da Silva's presidency, the Brazilian government outsourced a great deal of activities related to China to a private institution, the Institute for International Cooperation (ICOOI). ${ }^{10}$ Firstly, ICOOI helped implement the government's intention to use the $30^{\text {th }}$ anniversary of Brazil-China diplomatic relations to advance co-operation between the two countries. To that end, the government launched a comprehensive programme of celebrations called 'Brazil-China: a necessary leap forward' that involved activities in Brazil as well as in China. ${ }^{11}$ The first activities were two seminars held in Rio de Janeiro; the first, 'Brazil-China: a necessary leap forward' in April 2003, just three months after the start of Lula da Silva's first term; and the second. 'China and Brazil in the $21^{\text {st }}$ Century', in April 2004 (MDIC-Brazil 


\section{Network Governance and the Making of}

Brazil's Foreign Policy Towards China...

2004; BNDES 2004). ${ }^{12}$ Opening the 2003 seminar, Lula da Silva declared that 'this event is an example of how all sectors of society can collaborate in order to push the strategic and necessary partnership with China forward' (da Silva 2003a). In fact, several features of these two events conformed to the idea of having a network of actors working together to formulate a specific public policy. First, they were organised by state as well as non-state actors: Rio de Janeiro's Commercial Association, and ICOOI. Second, they were hosted by BNDES (and not the MRE). Third, they were attended by a wide range of state and non-state actors, including the Ministry of Mines and Energy (MME), the Ministry of Science and Technology (MCT), MRE, MDIC, the governor and mayor of Rio de Janeiro, BNDES, the state-owned oil company Petrobrás, the aeroplane manufacturer Embraer, the tobacco producer Souza Cruz, and the mining company Companhia Vale do Rio Doce (CVRD, later renamed Vale (da Silva 2003a; Agência Brasil 2003).

Besides these two seminars, the most important activities were Lula da Silva's state visit to China in May 2004 and the Expo-China that took place in Beijing in August the same year (Mendes 2004). Apart from the state visit, ${ }^{13}$ the organisation of all the activities was outsourced to ICOOI, while Itamaraty was in charge of co-ordination. ${ }^{14}$ Large Brazilian companies like Petrobrás, Banco do Brasil, Caixa Econômica Federal, CVRD and Embraer also played an important role, notably by supporting Expo-China financially (Mendes 2004).

Secondly, ICOOI played a key role in organising the 2008 APEX countrywide trade mission to China. It organised, under APEX's co-ordination, meetings and conferences in 52 Chinese cities and in the main Brazilian cities (MDIC-Brazil 2008b). In addition, ICOOI published a magazine, Negócios com o Brasil (Business with Brazil), which was distributed to participants. It was the first magazine fully written in Chinese about doing business in Brazil (ICOOI 2008). 
ICOOI also helped MRE to establish the China-Brazil Centre for Climate Change and Energy Technology Innovation, a joint venture between the Federal University of Rio de Janeiro/COPPE and the University of Tsinghua (COPPE 2009).

The government's partnership with the Brazil-China Business Council (CEBC) was another example of the strong connection between state and non-state actors. The council was established in 2004 (Agência Estado 2004). The process was led by the mining company CVRD, which was interested in levelling Brazil-China relations in order to secure a good business environment between the two countries. CEBC's first president was Roger Agnelli, and its first executive director was Renato Amorim, head of the institutional relations department of the CVRD. Before joining the CEBC and CVRD, Amorim had been a diplomat, working in the Brazilian embassy in Beijing. According to a CEBC representative, the idea behind inviting Amorim to serve as executive director was to have someone who knew China well, and would be able to communicate with government.

The council was created to pool the resources of big Brazilian exporting companies like Embraer, Petrobrás, Sadia (agribusiness) and Banco do Brasil (banking) which shared an interest in China, thus consolidating their chances of shaping the government's China policy. ${ }^{15}$ It soon became an important source of information on China and China-Brazil relations, mostly in the form of brief bilateral trade and investment analyses, policy recommendations, and overviews of the Chinese economy. It also organised large international conferences which brought together Chinese, Brazilian and international experts every two years. ${ }^{16}$

The council's research activities intensified with the arrival of the economist Antônio Barros de Castro as scientific and editorial advisor. ${ }^{17}$ At that stage, he was one of the most controversial but 
consistent analysts of the effects of China's rise on Brazil. As the BNDES director of strategic planning, Barros de Castro had argued that 'the biggest challenge for Brazil was to adjust its economy to a world rapidly changing because of the 'China effect' (Dantas 2007). According to Barros de Castro $(2008 ; 2012)$ the world economic order was steadily becoming sino-centred. He presented his ideas within the BNDES and directly to the government in 2007/2008 (Dantas 2007; Romero 2011), asserting that it was essential for Brazil to have a long-term strategy for dealing with an increasingly sino-centric world.

The information collected and the knowledge produced by the council was passed directly to the government, and, in this sense, it was important to support decisions about China. Firstly, the directors of CEBC met members of the government several times between 2003 and 2010. ${ }^{18}$ Secondly, the CEBC was one of the most important participants in the Brazilian government's campaign to compile a productive commercial agenda in respect of China. Besides the CEBC, this comprehensive task force consisted of several state and non-state actors. This initiative resulted in a report entitled Agenda China: Positive Actions for the Economic and Commercial Relations between China and Brazil (MDIC-Brazil 2008a). ${ }^{19}$ CEBC played a crucial role not only because of the information it already had about China, but also because its members were directly involved in preparing the report. Given the limited number of diplomatic staff members in the Beijing embassy, CEBC sent staff to help them collect and analyse information about China towards the report. ${ }^{20}$ Thirdly, CEBC played an important role in preparationsfor the meetings of the subcommittee for economic and trade issues of the China-Brazil High-Level Coordination and Cooperation Committee (COSBAN). ${ }^{21}$ Its participation in the subcommittee was first mentioned in the 2010 Joint Action Plan between Brazil and China, and then formalised in the China-Brazil 10-year cooperation 
programme signed in 2012, making CEBC the only non-state institution with such a role in China-Brazil relations.

The organisations and individuals mentioned above (ICOOI, CEBC, and Barros de Castro) played central roles in making Brazil's China policy, mostly because they could provide the government with information about China. This was relevant in a context in which the government lacked the capacity to deal with the multidimensional challenges posed by China's rise. In a cable sent to the Department of State in Washington DC in 2004, the US embassy in Brasilia quoted Oswaldo Biato, chief of Itamaraty's Asia and Oceania Division, as saying that the support of CEBC and other non-state actors was essential 'because official trade promotion agencies like Itamaraty's Trade Promotion Department [were] too small and inexperienced to handle large activities across the two countries' (US Embassy 2004). It also quoted Itamaraty representatives as stating that 'few academics or public servants, let alone business people in Brazil, [were] knowledgeable about China' (US Embassy 2004). In this context, the engagement with non-state actors was a way of overcoming the lack of financial resources and knowledge about China.

Even though Itamaraty had to share foreign policy-making with other actors, several institutional mechanisms were put in place to ensure that it would still play a central role. ${ }^{22}$ For example, at the end of Lula da Silva's second term, a 'China desk' was created under Itamaraty's department of international finance to facilitate co-ordination with other domestic actors about relations with China, especially in the areas of economics and finance. ${ }^{23}$

CEBC and ICOOI were naturally pro-China. For them, the Asian country was mostly a promising partner rather than a discouraging competitor $(\mathrm{CEBC} \mathrm{n} / \mathrm{d})$. Therefore, they believed the Brazilian authorities should invest more in promoting bilateral relations than in 
blocking them. This position was strongly challenged by a group of actors led by the Federation of Industries of Sao Paulo (FIESP) and the National Confederation of Industry (CNI), who pointed to the dangers that China could pose to Brazil in general, and Brazilian industry in particular. Their activism became more vocal after the Brazilian government's recognition, in 2004, of China as a market economy (Cordeiro 2004). ${ }^{24}$ This decision was also opposed in the Brazilian Congress, and several members, notably members of the largest opposition party, the Brazilian Social Democracy Party (PSDB), tried to have the decision revoked (Cardoso 2015). The efforts of these actors were enough to encourage the Brazilian government not to fully recognise China as a 'market economy' at that $_{\text {point. }}{ }^{25}$

Besides the 'market economy status' issue, FIESP and CNI put also strong pressure on Lula da Silva's administration to implement specific measures against an 'imminent invasion of Chinese products in Brazil' (Cordeiro 2004). As a result, in 2005 they both asked the administration to introduce 'safeguards' against certain Chinese products (Nunes 2005; Agência Brasil 2005). ${ }^{26}$ Neither Lula da Silva's administration nor the CEBC favoured this approach; both preferred to avoid open conflicts with the Chinese government. In search of a solution that could accommodate different views, the CEBC organised, in September 2005, a visit to China which brought together opponents and supporters of trade 'safeguards' (CEBC 2005). According to Renato Amorim, CEBC's executive director, 'there were several Brazilian companies making money in China, and there was no interest in becoming hostile against a country that was contributing to Brazil's growth' (Trevisan 2005). After long months of negotiation, the two governments reached an agreement in February 2006 that avoided trade 'safeguards', but secured China's commitment to restraining its exports to Brazil instead (MDIC-Brazil 2006). 
In late 2005, the Brazilian industrial sector pushed up the pressure by starting to suggest that China was contributing to Brazil's 'deindustrialisation'. The first person to introduce this theme was Rubens Ricupero (2005), former Brazilian ambassador to Washington and former general secretary of UNCTAD, who claimed that the government's unwillingness to take a tougher stance on Chinese imports was leading to Brazil's deindustrialisation. In November 2005, Ricupero, along with the former ambassadors Sérgio Amaral and Rubens Barbosa (both of whom were close to the PSDB, the largest opposition party), organised, with the support of FIESP, an international conference on this theme which brought together experts, business leaders and government officials (Agência Indusnet FIESP 2005).

Faced with strong pressures from industry, Lula da Silva's administration occasionally adopted more defensive positions in respect of relations with China. Besides concluding the agreement with China about restraining its exports to Brazil, the government increased the number of anti-dumping measures, ${ }^{27}$ and - most importantly, decided not to formally recognise China as a market economy.

However, despite this sharp divergence of views between the pro-China and anti-China groups, their interactions were not based solely on competition. There were many instances of co-operation, especially after 2007. First, CNI helped to draft the 'Agenda China'. Second, FIESP became a member of the CEBC. Furthermore, Sérgio Amaral, who used to be an advisor to FIESP and who organised, together with Rubens Barbosa, the 2005 conference on deindustrialisation, became the director of CEBC in 2009. This shows that, even though these actors had different views of China policy, they also collaborated in order to improve Brazil's response to China at the start of the $21^{\text {st }}$ century. 


\section{Network Governance and the Making of \\ Brazil's Foreign Policy Towards China...}

\section{Dilma Rousseff's presidency (2011-2014)}

Despite the leadership change in 2011, the government's goal of intensifying relations with China continued. Rousseff's state visit to China in April 2011 was among the first of her presidency (Hugueney 2011). COSBAN, the main bilateral organisation, convened more often during Rousseff's first term (in 2012, 2013 and 2015) than during Lula da Silva's two terms (in 2006 only).

Following Rousseff's ascent to the presidency, the domestic context for making and implementing policy on China did not change substantially; the main actors involved in the policy process remained the same. However, two aspects should be noted. The first was the government's effort to improve co-ordination of the policy process. To this end, in 2011, Rousseff decided to strengthen the 'China Desk' by transforming it into an interministerial group, headed both by the MRE and MDIC (Correio 24horas 2011). According to Alessandro Teixeira, this represented an institutional innovation since it was the first time that an interministerial group was created to study a single country (Correio 24horas 2011).

The second was FIESP's shift from a defensive to a proactive posture about the 'China effect'. In a report released in 2014, FIESP stated that, even though the relationship remained problematic in some ways, the Brazilian government should regard China as a strategic priority, and adopt a pragmatic approach towards it (FIESP 2014: 1). This shift in FIESP's understanding of China increased the room for co-operation among domestic actors in Brazil, which had been opened in 2007 as CNI joined the network that prepared and implemented 'Agenda China'.

While the views of FIESP and other actors had converged, tensions between Vale and the government, which had already existed to some extent during the Lula da Silva years, ${ }^{28}$ intensified during 
Rousseff's presidency, leading eventually to the dismissal of Roger Agnelli as Vale's CEO in April 2011 (Mozee 2011). As one of Vale's shareholders, the state was able to enforce a change in the company's management. ${ }^{29}$ This shows that the co-operation between actors within and outside the state apparatus can also be hierarchical, since the government can use its authority to resolve conflicts of interest.

\section{Conclusion}

This study shows that the making of Brazil's China policy during the Lula da Silva administration and the first four years of the Rousseff administration involved a wide array of actors both inside and outside the state apparatus. The study identified these actors, and analysed their interactions. In fact, besides the MRE, traditionally the most engaged actor in Brazil's foreign policy, other actors such as the president, other ministries, state agencies, the development bank, state-owned and private companies, NGOs, consulting firms, peak associations, business councils and influential individuals participated, in some capacity, in the policy process.

This corresponded to the emergent pattern of rule in Brazil, which was based on network governance instead of the bureaucratic-hierarchical model. Even though several actors were involved in the policy process, the MRE, in lock-step with the presidency, continued to play a central role in managing the network. This shows that the making and implementation of Brazil's policy towards China took place in the 'shadow of hierarchy', combining, therefore, hierarchical and network forms of governance. This effort to co-ordinate the network through a certain degree of hierarchy was consolidated with the establishment of the 'China desk' by Itamaraty in 2010, and the 'interministerial China group' in 2011.

The study has demonstrated that the interactions among these actors were largely informal, recurrent, but irregular. They jointly 
organised conferences, seminars, commercial missions, reports, state visits, and investment projects, among other activities. The organisation of 'Brazil-China: a Necessary Leap Forward' in 2004; the negotiation of safeguards in 2005-6; and the adoption of 'Agenda China' in 2008 are concrete examples of the participation of both public and private actors in the formulation and implementation of Brazil's policy towards China.

The relations between these actors were based, above all, on resources exchange. Government and non-government actors contributed information, knowledge, capital, ideas, and political and institutional support to the formulation and implementation of the policy. Despite periods of conflict between domestic actors about how to cope with China, co-operation and co-ordination were the general trends. This challenges the recurrent characterisation of China policy as an area of conflict between pro-China and anti-China camps. The study shows that there were several instances of co-operation between actors with previously contrasting views about China. Furthermore, the change in FIESP's position in 2014 indicates the gradual emergence of a consensus among Brazilian stakeholders about China's strategic relevance, and the need to adopt a proactive policy towards it.

Even though numerous actors were involved in formulating and implementing Brazil's China policy, many others were excluded. Indeed, NGOs, trade unions and universities were rarely involved. This view has been corroborated by Adhemar Mineiro, an economist at the Inter-Union Department of Statistics and Socio-Economic Studies (DIEESE) and a member of the NGOs Pre-Salt Observatory and REBRIP. In his view, even though some sectors of civil society worried about the impact of China on Brazil, their voices were rarely heard. ${ }^{30}$ Hence, given that China is featuring ever larger in Brazil's domestic and foreign policies in the $21^{\text {st }}$ century, the challenge lying ahead for Brazilian authorities is to level the playing field so that 
opportunities for participation in the policy process are not limited to a narrow network of actors.

\section{Acknowledgements}

I would like to thank Dawisson Belém Lopes, Carlos Aurélio Pimenta de Faria, and the journal referees for their helpful comments on earlier drafts of this article.

\section{References}

Agência Brasil. 2003. 'Relações Brasil-China São Tema de Seminário Da Associação Comercial Do Rio'. Available at http://memoria.ebc. com.br/agenciabrasil/noticia/2003-04-28/relacoes-brasil-china-sao-tema-de-s eminario-da-associacao-comercial-do-rio. [Accessed on 20 October 2015]

2005. 'Presidente da CNI pede salvaguardas para frear entrada de produtos chineses'. 5 May. Available at http://agenciabrasil. ebc.com.br/noticia/2005-05-06/presidente-da-cni-pede-salvaguardas-para-fre ar-entrada-de-produtos-chineses. [Accessed on 21 October 2015]

Agência Estado. 2004. 'Conselho Empresarial Brasil-China Será Oficializado Nesta Sexta'. Available at http://economia.estadao.com.br/noticias/ geral,conselho-empresarial-brasil-china-sera-oficializado-nesta-sexta,200404 23p19428. [Accessed on 20 October 2015]

Agência Indusnet FIESP. 2005. 'Seminário Internacional Industrialização, Desindustrialização E Desenvolvimento 'Juros Altos São a Principal Causa Da Desindustrialização Brasileira, Apontam Economistas”'. Siamfesp Em Ação. Available at http://www.siamfesp.org.br/novo/conteudo/noticias/acao_ txt.asp?id=69. [Accessed on 21 October 2015]

Alden, Chris and Amnon Aran. 2012. Foreign Policy Analysis: New Approaches. New York: Routledge.

Amorim, Celso. 2003. 'Discurso Por Ocasião Da Transmissão Do Cargo de Ministro de Estado Das Relações Exteriores'. MFA-Brazil. Available at 
Network Governance and the Making of

Brazil's Foreign Policy Towards China...

http://www.itamaraty.gov.br/sala-de-imprensa/notas-a-imprensa/2003/01/dis curso-proferido-pelo-embaixador-celso-amorim. [Accessed on 20 October 2015]

Antunes, Claudia. 2001. 'Encontro Vermelho: Lula Vai à China Após Negociar Por 7 Anos'. Folha de S Paulo. Available at http://www1.folha.uol. com.br/fsp/brasil/fc1305200118.htm. [Accessed on 21 October 2015]

Armijo, Leslie Elliott. Forthcoming. 'The public bank trilemma: Brazil's new developmentalism and the BNDES'. In Peter Kingstone and Timothy J Power (eds). Democratic Brazil Ascendant. Pittsburgh: Pittsburgh University Press. Available at http://www.leslieelliottarmijo.org/wp-content/uploads/ 2011/02/Armijo-BNDES-13-July-24-double-sp.docx. [Accessed on 21 October 2015]

Barber, Lionel and Jonathan Wheatly. 2009. 'Interview: President Luiz Inácio Lula Da Silva'. Financial Times. Available at http://www.ft.com/cms/s/0/ e0357680-cbbf-11de-924d-00144feabdc0.html\#axzz2AceEVpgC. [Accessed on 2 October 2015]

Barbosa, Alexandre de Freitas and Ricardo Camargo Mendes. 2008. 'A Ascensão Chinesa E Os Desafios Da Politica Externa Brasileira’. Nueva Sociedad.

Barros, Sebastião do Rego. 1998. 'A Execução Da Política Externa Brasileira: Um Balanço Dos últimos 4 Anos’. Revista Brasileira de Política Internacional 41 (2): 18-28.

Bevir, Mark. 2010. Democratic Governance. Princeton, NJ: Princeton University Press.

Biato Junior, Oswaldo. 2010. A Parceria Estratégica Sino-Brasileira: Origens, Evolução E Perspectivas (1993-2006). Brasília.

BNDES. 2004. 'Brasil-China No Século XXI'. Available at http://www.bndes.gov.br/SiteBNDES/bndes/bndes_pt/Institucional/Publicac oes/Paginas/brasil_china.html. [Accessed on 22 October 2015]

2007a. 'BNDES Assina Contrato de Financiamento de R \$ 462,5 Milhões

Para Sadia'. Available at http://www.bndes.gov.br/SiteBNDES/bndes/ bndes_pt/Institucional/Sala_de_Imprensa/Noticias/2007/20070510_not102_ 07.html. [Accessed on 23 October 2015] 
2007b. 'BNDES Assina Contratos de R\$ 4,5 Bi Para O Projeto Gasene'. Available at http://www.bndes.gov.br/SiteBNDES/bndes/bndes_pt/ Institucional/Sala_de_Imprensa/Noticias/2007/20071227_not287_07.html. [Accessed on 2 October 2015]

Börzel, Tanja A. 2010. 'European governance: negotiation and competition in the shadow of hierarchy'. Journal of Common Market Studies 48 (2): 191-219.

Bresser-Pereira, Luiz Carlos. 2002. 'A Reforma Gerencial Do Estado de 1995'. Revista de Administração Pública 34 (4): 7-26.

2007. 'Burocracia Pública E Reforma Gerencial'. Revista Do Serviço Público, Special Issue, 29-48.

Cardoso, Daniel. 2015. Coping with a Rising Power: Understanding the Making of Brazil's Foreign Policy towards China through Network Governance. $\mathrm{PhD}$ thesis. Freie Universität Berlin.

Cardoso, Fernando Henrique. 1995. 'Discurso Proferido Na Solenidade de Instalação Do Conselho de Reforma Do Estado, No Palácio Do Planalto'. MARE, Ministério da Administração Federal e Reforma do Estado.

Cason, Jeffrey W and Timothy J Power. 2009. 'Presidentialization, pluralization, and the rollback of Itamaraty: explaining change in Brazilian foreign policy making in the Cardoso-Lula era'. International Political Science Review 30 (2): 117-40.

CEBC. 2005. Carta Da China, 11. Rio de Janeiro. Available at http://www.cebc.org.br/sites/default/files/carta_da_china_n.11.pdf. [Accessed on 20 October 2015]

n/d. 'About Us I CEBC - Conselho Empresarial Brasil-China'. CEBC

Brazil. Available at http://www.cebc.org.br/en/about-cbbc/who-we-are/ about-us. [Accessed on 20 October 2015]

Cervo, Amado Luiz. 2012. 'Brazil in the current world order'. Austral: Brazilian Journal of Strategy \& International Relations, 2, 35-57.

COPPE. 2009. 'Coppe E Universidade de Tsinghua Inauguram Centro Brasil-China'. internal-pdf://Pré-visualização de "Planeta COPPE"-2988793600/Pré-visualização de "Planeta COPPE”.pdf. [Accessed on 22 October 2015] 
Network Governance and the Making of Brazil's Foreign Policy Towards China...

Cordeiro, Elisângela. 2004. 'Fiesp Quer Proteger a Indústria Brasileira Contra Os Importados Chineses'. Agência Brasil. Available at http://agenciabrasil.ebc.com.br/noticia/2004-11-16/fiesp-quer-proteger-indus tria-brasileira-contra-os-importados-chineses. [Accessed on 4 October 2015]

Correio 24horas. 2011. 'Governo Cria Grupo China Para Definir Estratégia de Longo Prazo Com Chineses'. Available at http://www.correio24horas.com.br/ detalhe/noticia/governo-cria-grupo-china-para-definir-estrategia-de-longo-pr azo-com-chineses/. [Accessed on 24 October 2015]

da Silva, Elaini Cristina Gonzaga, Priscila Spécie and Denise Vitale. 2010. 'Atual Arranjo Instituticional da Política Externa Brasileira'. IPEA, Texto para discussão, nº 1489 .

da Silva, Luiz Inácio Lula. 2001. 'China: O Gigante E a Globalização'. La Insignia. Available at http://www.galizacig.com/actualidade/ 200105/lainsignia_china_o_gigante_e_a_globalizacao.htm. [Accessed on 24 October 2015]

2003a. 'Discurso de Posse'. Available at http://www.fiec.org.br/ artigos/temas/discurso_de_posse_do_presidente_Luiz_Inacio_Lula_da_Silva .htm. [Accessed on 20 October 2015]

2003b. 'Discurso Na Solenidade de Abertura Do Seminário Brasil-China'. Rio de Janeiro: BNDES.

2007. Interviewed by Stephen Sackur on Hard Talk, BBC. Available at https://www.youtube.com/watch?v=1qh-ZzjbvJc\&feature=youtube_gdata_ player. [Accessed on 19 October 2015]

Dantas, Fernando. 2007. 'BNDES Repensa Estratégia Nacional'. 26 March. Available at http://www.jornalcana.com.br/noticia/Jornal-Cana/ 25232+BNDES-repensa-estrategia-nacional. [Accessed on 20 October 2015]

de Castro, Antônio Barros. 2008. 'From semi-stagnation to growth in a sino-centric market'. Revista de Economia Política 28 (1): 3-27.

2012. In China's Mirror. Working Paper, Center for Latin American Studies, 30 (0). Available at http://www.jbc.org/ content/268/31/23087.short. [Accessed on 19 October 2015]

de Faria, Carlos Aurélio Pimenta, Dawisson Belém Lopes and Guilherme Stolle Paixão e Casarões. 2013. 'Itamaraty on the move: institutional and political 
change in the Brazilian Foreign Service under Lula Da Silva's presidency (2003-2010)'. Bulletin of Latin American Research 32 (4): 468-82.

de Faria, Carlos Aurélio Pimenta. 2008. 'Public opinion and foreign policy: insulation, politicization and reform in the production of Brazilian foreign policy'. Revista Brasileira de Política Internacional 51 (2): 80-97.

'Itamaraty and Brazilian foreign policy: from isolation to the search for coordination amongst governmental actors and cooperation with societal actors'. Contexto Internacional 34 (1): 311-55.

de França, Cassio Luiz and Michelle Ratton Sanchez. 2009. 'A Horizontalização Da Política Externa Brasileira'. Valor Econômico. Available at http://www2.senado.leg.br/bdsf/bitstream/handle/id/449319/ noticia.htm?sequence $=1$. [Accessed on 22 October 2015]

de Souza, Amaury. 2001. 'A Agenda Internacional Do Brasil: Um Estudo Sobre a Comunidade Brasileira de Política Externa'. Rio de Janeiro: CEBRI. Available at http://www.wilsoncenter.org/sites/default/files/brazil. agendainternacionaldobrasil.pdf. [Accessed on 20 October 2015]

Deutsche, Welle. 2009. 'First BRIC summit concludes'. June. Available at http://www.dw.de/first-bric-summit-concludes/a-4335954. [Accessed on 21 October 2015]

Evans, Peter B, Harold Karan Jacobson and Robert D Putnam (eds). 1993. Double-Edged Diplomacy: International Bargaining and Domestic Politics. Los Angeles: University of California Press.

Fernández Jilberto, Alex E and Barbara Hogenboom (eds). 2010. Latin America Facing China: South-South Relations beyond the Washington Consensus. New York: Berghahn Books.

FIESP. 2014. 'Propostas de Integração Externa Da Indústria'. São Paulo. Available at http://www.fiesp.com.br/arquivo-download/?id=159608. [Accessed on 20 October 2015]

Figueira, Ariane. 2009. Processo Decisório Em Política Externa No Brasil. Universidade de São Paulo.

Government of Brazil. 1995. 'Plano Diretor Da Reforma Do Aparelho Do Estado'. Brasília: MARE. Available at http://www.cebes.org.br/media/ File/Plano\%20Diretor\%20da\%20Reforma\%20do\%20Aparelho\%20do\%20E stado.pdf. [Accessed on 23 October 2015] 
Network Governance and the Making of

Brazil's Foreign Policy Towards China...

2004. 'Plano de Gestão Do PPA 2004-2007'. Brasilia: Ministry of Planning. Available at http://www.planejamento.gov.br/secretarias/upload/ Arquivos/spi/plano_plurianual/modelo_gestao/081009_PPA_MG_planoGes. pdf. [Accessed on 22 October 2015]

2006. DECOM Report, 10. Brasília: Department of Trade Defense. Available at http://www.desenvolvimento.gov.br/arquivos/dwnl_ 1197027800.pdf. [Accessed on 20 October 2015]

Hearn, Adrian, Jose Luis Leon-Manriquez, Adrian H Hearn and Jose Luis Leon-Manriguez. 2011. China Engages Latin America: Tracing the Trajectory. Boulder, Colorado: Lynne Rienner.

Hill, Christopher. 2002. The Changing Politics of Foreign Policy. New York: Palgrave Macmillan.

Hirst, Monica, Maria Regina Soares de Lima and Letícia Pinheiro. 2010. 'A Política Externa Brasileira Em Tempos de Novos Horizontes E Desafios'. Análise de Conjuntura, $\mathrm{n}^{\circ}$ 12. Available at http://www.nuso.org/ upload/portugues/2010/2.\%20Hirst\%20EP\%2010.pdf. [Accessed on 20 October 2015]

Hugueney, Clodoaldo. 2011. 'Um Olhar Sobre O Futuro Das Relações Brasil-China'. Revista Interesse Nacional. Available at http://interesse nacional.uol.com.br/index.php/edicoes-revista/um-olhar-sobre-o-futuro-das-r elacoes-brasil-china/. [Accessed on 24 October 2015]

Huntington, Samuel P. 1991. 'The third wave of democracy'. Journal of Democracy 2(2): 12-34.

ICOOI. 2008. Negócios com o Brasil. ICOOI: Rio de Janeiro.

Lessa, Antônio Carlos, Leandro Freitas Couto and Rogério de Souza Farias. 2009. 'Planned foreign policy: pluriannual plans and Brazil's international action, from Cardoso to Lula (1995-2008)'. Revista Brasileira de Política Internacional 52 (1): 89-109.

LLX Logística SA. 2009. 'LLX Aumentará Capital Em R \$ 600 Milhões E Terá BNDESPAR Como Acionista'. Available at http://www.acionista. com.br/home/1lx/160309_aumento_capital.pdf. [Accessed on 20 October 2015]

Lula, Edla. 2004. 'Especial China 2 - Amazônia E Objetos Indígenas Despertam Curiosidade'. Agência Brasil. Available at http://agenciabrasil. 
ebc.com.br/noticia/2004-05-18/especial-china-2-amazonia-e-objetos-indigen as-despertam-curiosidade. [Accessed on 22 October 2015]

Macleod, Alex. 2002. 'Civil society and foreign policy making in liberal democracies'. In ISA, 43rd Annual Convention of the International Studies Association, 24-27 March 2002, New Orleans. Available at http://isanet.ccit.arizona.edu/noarchive/macleod.html\#_ftnref7. [Accessed on 23 October 2015]

Marsh, David. 2008. 'Understanding British government: analysing competing models'. British Journal of Politics \& International Relations 10 (2): 251-68.

Mayntz, Renate. 1998. New Challenges to Governance Theory. Jean Monet Chair Paper 98 (50), European University Institute.

MDIC-Brazil. 2004. 'Seminário No BNDES Debate Relações Brasil-China'. Available at http://investimentos.mdic.gov.br/portalmdic/sitio/ interna/noticia.php?area=1\&noticia=5773. [Accessed on 22 October 2015]

2006. 'Brasil Finaliza Acordo Para Autolimitação de Exportações Chinesas'. MDIC-Brazil. 9 February. Available at http://www.mdic.gov.br/ sitio/interna/noticia.php? area $=5 \&$ noticia $=6866$. [Accessed on 24 October 2015]

2008a. 'Agenda China Será Lançada Amanhã Em Brasília (Agenda China will be launched tomorrow)'. Available at http://www.mdic.gov.br/ portalmdic/sitio/sala-imprensa/aviso.php?noticia $=8369$. [Accessed on 21 October 2015]

. 2008b. 'Estratégia Da Apex-Brasil Para a China'. Available at http://www.desenvolvimento.gov.br/sitio/interna/noticia.php?area=1\&notici $\mathrm{a}=8379$. [Accessed on 20 October 2015]

Mendes, Sandra. 2004. 'Expo Brasil China Exposição Mostra Potencial Da Economia Brasileira Na China'. Available at http://www1.caixa. gov.br/imprensa/imprensa_release.asp?codigo=4801945\&tipo_noticia=28. [Accessed on 22 October 2015]

Milner, Helen. 1997. Interests, Institutions, and Information. Princeton, New Jersey: Princeton University Press.

Moravcsik, Andrew. 1994. Why the European Union Strengthens the State: Domestic Politics and International Cooperation. CES Working Paper 52. Available at http://aei.pitt.edu/9151/ [Accessed on 22 October 2015] 
Network Governance and the Making of

Brazil's Foreign Policy Towards China...

1997. 'Taking preferences seriously: a liberal theory of international politics: erratum'. International Organization 52 (1): 513-33.

Mozee, Carla. 2011. 'Brazilian mining giant Vale CEO Agnelli to depart'. MarketWatch. Available at http://www.marketwatch.com/story/brazilianmining-giant-vale-ceo-agnelli-to-depart-2011-04-01. [Accessed on 22 October 2015]

Nunes, Julian Cézar. 2005. 'Fiesp Quer Mudar MP 232, Política Econômica E Abertura Para a China'. Agência Brasil. 2 April. Available at http://memoria.ebc.com.br/agenciabrasil/noticia/2005-02-04/fiesp-quer-mud ar-mp-232-politica-economica-e-abertura-para-china. [Accessed on 20 October 2015]

Pamplona, Nicola. 2009. 'LLX Consegue Financiamento de R\$ 1,3 Bi Do BNDES'. Estadão. 28 January. Available at http://www.estadao.com.br/ noticias/impresso,1lx-consegue-financiamento-de-r-1-3-bi-do-bndes,314092, 0.htm. [Accessed on 2 October 2015]

Pereira, Carlos and João Augusto de Castro Neves. 2011. Brazil and China: South-South Partnership or North-South Competition? Policy Paper. Washington DC: Brookings Institute.

Pinheiro, Letícia and Carlos RS Milani (eds). 2012. Política Externa Brasileira: As Práticas Da Política E a Política Das Práticas. Rio de Janeiro: Editora FGV.

Ramanzini Júnior, Haroldo and Pedro Feliu Ribeiro. 2013. "As Relações Bilaterais Brasil-China: Uma Relação Em Processo de Afirmação." Carta Internacional 8 (1): 165-87.

Reuters. 2008. "BNDES Libera R\$ 7,3 Bi Para Vale Investir No Brasil." Estadão. Available at: http://www.estadao.com.br/noticias/economia, bndes-libera-r-73-bi-para-vale-investir-no-brasil,149399,0.htm. [Accessed on 20 October 2015]

Ricupero, Rubens. 2005. “A Desindustrialização Como Projeto.” Folha de S. Paulo. October 10. Available at: http://www1.folha.uol.com.br/fsp/dinheiro/ fi0210200505.htm. [Accessed on 22 October 2015]

Risse, Thomas. 2013. "Foreign Policy Analysis and the Governance Turn" in Fredrik Bynander and Stefano Guzzini (eds), Rethinking Foreign Policy. Milton Park, Abingdon, Oxon; New York: Routledge, 176-85. 
Robertson, Susan, Karen Mundy, Antoni Verger and Francine Menashy. 2012. Public Private Partnerships in Education: New Actors and Modes of Governance in a Globalizing World. Cheltenham: Edward Elgar Publishing.

Romero, Cristiano. 2011. 'A China E O Futuro Do Brasil, Segundo Barros de Castro'. Valor Econômico. Agosto. Available at http://www.valor.com.br/ valor-investe/casa-das-caldeiras/986394/china-e-o-futuro-do-brasil-segundobarros-de-castro. [Accessed on 20 October 2015]

Rosenau, James N (ed). 1967. Domestic Sources of Foreign Policy. First Edition. New York: The Free Press.

Shambaugh, David L. 2013. China Goes Global: The Partial Power. Oxford; New York: Oxford University Press.

Shanshan, Wang. 2004. "Amazon Culture Comes to China." China Daily. Available at: http://www.chinadaily.com.cn/english/doc/2004-06/ 01/content_335543.htm. [Accessed on 23 October 2015]

Sikkink, Kathryn. 2009. "The Power of Networks in International Politics" in Miles Kahler (ed), Networked Politics: Agency, Power and Governance. New York: Cornell University Press, 228-47.

Silva, Paulo Bernardo and Helena Kerr do Amaral. 2007. 'Perspectivas Da Gestão Pública No Brasil Contemporâneo’. Revista Do Serviço Público, 7-18.

Snyder, Richard Carlton, Henry W Bruck and Burton M Sapin (eds). 1962. Foreign Policy Decision Making: An Approach to the Study of International Politics. New York: The Free Press.

Sørensen, Eva and Jacob Torfing (eds). 2009. 'Making governance networks effective and democratic through metagovernance'. Public Administration 87 (2): 234-58.

Sørensen, Eva and Jacob Torfing (eds). 2007. Theories of Democratic Network Governance. Basingstoke and New York: Palgrave Macmillan.

Spektor, Matias. 2011. 'Brazil-China: what's next after Rousseff's visit?' Americas Quarterly. Available at http://www.americasquarterly. org/node/2411.

Spinetto, Juan Pablo. 2011. 'Vale says shareholders seeking replacement for CEO Agnelli'. Bloomberg. Available at http://www.bloomberg.com/news/ 
Network Governance and the Making of

Brazil's Foreign Policy Towards China...

articles/2011-04-01/vale-s-main-shareholders-group-seeking-replacement-fo r-ceo-roger-agnelli [Accessed on 4 December 2015]

Strauss, Julia C and Ariel C Armony. 2012. From the Great Wall to the New World: China and Latin America in the 21st Century. Cambridge University Press.

Trevisan, Cláudia. 2005. 'Empresas Divergem Ao Negociar Com China'. Folha de S Paulo. 20 September. Available at http://www1.folha.uol.com.br/ folha/dinheiro/ult91u100523.shtml. [Accessed on 20 October 2015]

US Embassy in Brasilia. 2004. 'Scene setter: President Lula's visit to China'. Available at http://wikileaks.org/cable/2004/05/04BRASILIA1185.html. [Accessed on 19 October 2015]

2009. 'Understanding Brazil's Foreign Ministry, Part 3: Inter-agency competition'. Available at http://www.wikileaks.org/plusd/cables/09 BRASILIA190_a.html. [Accessed on 22 October 2015]

Waltz, Kenneth Neal. 1979. Theory of International Politics. Reading, MA: Addison-Wesley.

\section{Notes}

1. The analysis focuses only on Rousseff's first term, since at the time of writing (September 2015) her second term had just begun.

2. For a good overview of the main schools of thought about governance in general and network governance in particular, see (Sørensen and Torfing 2007).

3. For concrete examples of network governance, see, among others, Bevir (2010), Börzel (2009), Robertson et al. (2012).

4. The Pluriannual Plan is the instrument used by the government to guide its medium-term activities, according to the goals set out in its strategic plan. For an assessment of these plans with a focus on the MRE, see Lessa, Couto and Farias (2009: 89ff).

5. One example of this type of network is that formed by the Lula da Silva administration to implement the directives agreed within the IBAS grouping of Brazil, India and South Africa (Faria 2012). 
6. For studies of China's role in Latin America, see Fernaìndez Jilberto and Hogenboom (2010); Hearn et al. (2011); Strauss and Armony (2012).

7. In a 2007 interview on the BBC talk show Hard Talk, Lula da Silva stressed that Itamaraty and the presidency had the final say over foreign policy (da Silva 2007).

8. The co-operation between these countries led to the establishment of the BRICS grouping, which held its first summit of heads of state in Russia in 2009 (Deutsche Welle 2009).

9. This meeting was particularly important, not only because Lula da Silva was still a candidate, but also because his visit to China ended 12 years of no high-profile meetings between his party, PT, and the Chinese Communist Party (Antunes 2001).

10. This institution was led by Wladimir Pomar, a former member of PT (the president's party), with extensive historical links, connections to and knowledge about China.

11. Interview with Wladimir Pomar, former president of ICOOI, conducted by the author in Rio de Janeiro, Brazil, December 2012.

12. There is little information available online about this programme. A brief summary of the activities and goals can be found on the BNDES website at http://www.bndes.gov.br/SiteBNDES/export/sites/default/bndes_pt/Galerias/ Arquivos/conhecimento/seminario/MarcoPolo.pdf.

13. During his state visit to China, Lula da Silva opened the exhibition 'Amazonia: Native Traditions' in Beijing. It was the first exhibition organised by a foreign country hosted by the Palace Museum in the Forbidden City. The exhibition was funded by CVRD and Embraer (Shanshan 2004; da Silva 2004).

14. Interview with Wladimir Pomar, former president of ICOOI, Rio de Janeiro, 2012.

15. The relationship between Lula da Silva's administration and large exporters to China grew more intense as the latter launched in 2007 its 'national champions' strategy, comprising support to specific firms deemed able to compete with large multinationals in global markets (Armijo forthcoming : 9). BNDES played a pivotal role in this strategy, either by providing these companies with billions of dollars' worth of credit at discounted rates, or by investing directly in them. Petrobrás (BNDES 2007b), Sadia (BNDES 2007a), Vale (Reuters 2008) and EBX (Pamplona 2009; LLX Logística SA 2009) benefited from these measures. 


\section{Network Governance and the Making of Brazil's Foreign Policy Towards China...}

16. All the material published thus far as well as information about activities organised since 2004 appear on CEBC's website at http://www.cebc.org.br/.

17. A former president of the BNDES (1992-1993), who remained in the institution as a special advisor to the president between 2004 and 2010 and the director for strategic planning between 2005 and 2007, Barros de Castro was one of the most important, well-known and respected economists in Brazil.

18. Meetings with the Brazilian authorities are listed on the $\mathrm{CEBC}$ website, at http://www.cebc.org.br/en/events/other-events.

19. The report is available at http://desenvolvimento.gov.br/agendachina/ index.php/sitio/inicial.

20. Interview with a former member of CEBC, Rio de Janeiro, Brazil, 4 December 2012.

21. The bilateral mechanism was created in 2004 during Lula da Silva's state visit to China. Modelled on pre-existing bilateral mechanisms with India, Russia and South Africa (Biato Junior 2010: 147), the goal of the institution was to cover all the areas in which Brazil and China co-operated.

22. Interview with Ricardo Schaefer, Deputy Secretary of the Ministry of Development, Industry and Foreign Trade (MDIC), conducted by the author in Brasilia, 2012.

23. Interview with Paulo Alves Neto, Brazil's MRE, Department of Asia and Oceania, conducted by the author in Brasilia, 2012.

24. This decision was made during Hu Jintao's first state visit to Brazil in November 2004. The international agreements and memoranda of understanding signed during this visit are available at http://dai-mre. serpro.gov.br/atos-internacionais/bilaterais/2004/.

25. The decision to give China the status of a market economy has to be taken and put into effect by CAMEX. By October 2015, the chamber had not yet made a decision in this respect.

26. A 'safeguard' is an emergency measure taken on a non-selective basis to temporarily restrict the importation of a product which is disrupting, or threatening to disrupt, a specific domestic industry.

27. In $2006,62.5 \%$ of all anti-dumping investigations started by the government were related to China (Department of Trade Defense 2006).

28. Lula da Silva's administration wanted Vale to invest more in steel mills in Brazil in partnership with Chinese companies in order to promote the 
diversification of Brazilian exports to China (Barber and Wheatly 2009). However, Vale did not manage to comply; during Lula da Silva's administrations, none of Vale's projects to set up steel mills in Brazil in co-operation with Chinese companies succeeded (Cardoso 2015: 169).

29. The Brazilian state has a direct stake in Vale, comprising $5 \%$ of shares and 12 golden shares; and an indirect one via government pension funds (Spinetto 2011).

30. Interview by the author, Rio de Janeiro, December 2012 .

\section{About the author}

Daniel Cardoso holds a $\mathrm{PhD}$ from Freie Universität Berlin (Germany) and Fudan University (Shanghai, China). He is the co-founder and co-director of the Berlin Forum on Global Politics (Germany), a nonprofit organization dedicated to the promotion of public understanding of global politics. Between 2010 and 2013, he was part of an international research team that analyzed the role of Macau in China's relations with the Portuguese Speaking Countries, hosted by the Center for Social Studies, University of Coimbra (Portugal). Daniel holds a first degree (2006) and Master degree (2009) in International Relations, from the University of Coimbra (Portugal). His main research interests are: Foreign Policy Analysis, China-Brazil relations and China in Latin America. 